Article

\title{
Do firms substitute earnings management methods? The case of the MENA region
}

\author{
Tarek Elkalla ${ }^{1}$ \\ 1 Arab Academy for Science, Technology \& Maritime Transport, Egypt; tarek.elkalla@gmail.com \\ * Correspondence: tarek.elkalla@gmail.com
}

Received: 28 October 2020; Accepted: 7 December 2020; Published: 7 December 2020

\begin{abstract}
The purpose of this paper is to empirically test whether firms substitute accruals-based earnings management with real activities-based earnings management or complement the two methods in the MENA region. Further, this paper seeks to investigate the impact of IFRS adoption on accruals-based earnings management. To test the research hypotheses, this paper employs a panel fixed-effects regression model for a sample of 798 non-financial listed MENA region firms over the period 2008-2015, inclusively. The research findings provide evidence that firms complement accruals-based and real activities-based earnings management methods rather than substituting one earnings management method for the other, which suggests that MENA firms conduct both methods concurrently to achieve earnings targets and are not constrained by the relative costs of employing a particular method. Furthermore, a significant positive association between GDP growth and accruals-based earnings management is found, which provides evidence that economic growth leads to a greater degree of accruals-based earnings management behavior in MENA region firms.
\end{abstract}

Keywords: Accruals-based earnings management; Real Earnings Management; IFRS Adoption; MENA region.)

JEL codes: M41

\section{Introduction}

Earnings management has become a significant issue as evidenced by an extensive body of literature. There are various definitions of earnings management. For example, Schipper (1989, p.92) defines earnings management as the "purposeful intervention in the external financial reporting process with the intent of obtaining some private gain." On the other hand, according to Healy and Wahlen (1999, p.368), "earnings management occurs when managers use judgement in financial reporting and in structuring transactions to alter financial reports to either mislead some stakeholders about the underlying economic performance of the company or to influence contractual outcomes that depend on reported accounting numbers."

Opportunistic earnings management occurs when accounting choices are selected in ways that are intentionally misleading to stakeholders with regard to the underlying economic performance of the firm (Healy and Wahlen, 1999). For example, managers could opportunistically bring forward reported earnings from the future to a current accounting period if a bonus award plan exists (Watts and Zimmerman, 1978).

There are three broad methods employed by firms to manage earnings: (i) accruals-based earnings management which involves altering estimates and accounting policies to change reported earnings; (ii) real activities-based earnings management which has direct cash flow consequences such as opportunistically reducing research and development expenditures to decrease expenses; and (iii) classification shifting-based earnings management which involves shifting the classification of certain 
items on the income statement. In most studies of earnings management, authors focus on one particular method. However, it is unlikely for firms to rely on only one technique for managing earnings. There is empirical evidence in the extant literature that firms can employ both accruals-based earnings management and real activities-based earnings management methods as complements to achieve earnings targets, or substitute one technique for the other based on their relative costs.

There is a paucity of research into whether firms substitute one earnings management method for another or complement the two methods by employing them concurrently, particularly in the case of the Middle East and North Africa (MENA) region. Thus, an objective of this paper is to investigate this dynamic. Further, since higher quality accounting standards associated with IFRS adoption should be expected to curb accruals-based earnings management behaviour and induce firms to shift toward real earnings management since real earnings management is not affected by IFRS adoption (Ho et al., 2015), then it is important to also investigate the impact of IFRS adoption on accruals-based earnings management. The MENA region provides a unique setting to investigate the impact of IFRS adoption on accruals-based earnings management since not all MENA region countries report under IFRS. Table 1 summarizes the adoption status of the MENA countries included in the study sample.

Table 1. IFRS Adoption Status of MENA Region Countries

\begin{tabular}{|c|c|c|}
\hline Country & Status of IFRS Adoption & Details for IFRS Adoption \\
\hline Bahrain & Adopted & $\begin{array}{l}\text { IFRS is required for all domestic public companies } \\
\text { and required or permitted for foreign companies. }\end{array}$ \\
\hline Egypt & Not adopted & $\begin{array}{c}\text { IFRS is required or permitted for foreign } \\
\text { companies only. Domestic companies report } \\
\text { under local standards. }\end{array}$ \\
\hline Jordan & Adopted & $\begin{array}{l}\text { IFRS is required for all domestic and foreign } \\
\text { companies. }\end{array}$ \\
\hline Kuwait & Adopted & $\begin{array}{l}\text { IFRS is required for all domestic public } \\
\text { companies. }\end{array}$ \\
\hline Oman & Adopted & $\begin{array}{l}\text { IFRS is required for all domestic public companies } \\
\text { and is under consideration for SMEs. }\end{array}$ \\
\hline Qatar & Adopted & $\begin{array}{l}\text { IFRS is required for all domestic public companies } \\
\text { and is required or permitted for SMEs. }\end{array}$ \\
\hline Saudi Arabia & Adopted & $\begin{array}{l}\text { IFRS is required for all domestic public companies } \\
\text { and the adoption for SMEs is in progress. }\end{array}$ \\
\hline Tunisia & Not adopted & IFRS is not permitted. \\
\hline United Arab Emirates & Adopted & $\begin{array}{l}\text { IFRS is required for all domestic public companies } \\
\text { and required or permitted for SMEs. }\end{array}$ \\
\hline
\end{tabular}

Note. This table presents details for the IFRS adoption status for the MENA region countries included in the study sample.

As shown in the Table 1, Bahrain, Kuwait, Oman, Qatar, Saudi Arabi, the United Arab Emirates, and Jordan report under IFRS while Egypt and Tunisia report under local standards. Therefore, this paper seeks to address two research questions: (i) what is the impact of IFRS adoption on accrualsbased earnings management for MENA firms? and (ii) are earnings management methods used as substitutes or complements by firms? By addressing these research questions, this paper provides significant contributions to the earnings management literature.

By examining whether earnings management methods are used as complements or substitutes, this paper expands the earnings management literature since the majority of studies focus on accrualsbased or real activities-based earnings management methods in isolation and do not consider whether these methods are employed as substitutes or complements by managers, which is particularly the case for research in the MENA region. However, this is of particular importance to regulators since it is essential to understand whether MENA firms are constrained in terms of employing accruals-based earnings management and thus shift toward real earnings management, or are able to employ both 
concurrently. In addition, by investigating the impact of IFRS adoption on accruals-based earnings management, this paper provides a contribution to the extant literature for the MENA region in particular since IFRS adoption should be expected to curb accruals-based earnings management behaviour, potentially inducing firms to shift toward real activities-based earnings management.

The remainder of this paper is organized as follows. Section 2 provides a review of the relevant literature and the development of hypotheses. Section 3 presents the research methodology adopted in this paper. In Section 4, the discussion of results is presented. Section 5 provides a conclusion, recommendations for future research, and discusses the research limitations.

\section{Literature Review and Hypothesis Development}

There is evidence in the extant literature that firms can employ both earnings management methods as complements to achieve earnings targets. On the other hand, evidence also shows that if accruals-based earnings management is constrained, managers can substitute it for real earnings management. Cohen and Zarowin (2010) argue that a firm's choice of an earnings management technique is a function of the costs of engaging in accruals-based earnings management as well as the capacity to do so. The costs associated with employing accruals-based earnings management include the scrutiny of regulators and auditors, and potential litigation penalties. Similarly, Doukakis (2014) argues that although accounting choices are subject to auditor scrutiny, real operating decisions are less subject to this scrutiny. According to Zhu et al. (2015), real earnings management is less likely to be constrained and discovered by auditors and regulators since operational decisions are more inherently under the expertise and discretion of management. They further argue that firms which employed a greater degree of accruals-based earnings management in previous years are likely to alternate to real earnings management in current and future periods as a result of the constraints of accruals-based earnings management. Further, Zang (2012) argues that firms encounter different constraints for both methods and provides evidence that the trade-off decision is dependent upon the relative costs of employing the two strategies. She explains that managers will utilize one earnings management technique when the other method is constrained.

Most empirical studies of the substitutability of earnings management methods find evidence of a substitution effect. In her study of US firms, Zang (2012) finds evidence of firms substituting the two methods. In other studies of US firms, Anagnostopoulou and Tsekrekos (2017) and Cohen et al. (2008) also find consistent evidence. Similarly, Zhu et al. (2015) investigate Chinese reverse merger firms and find that firms substitute the two methods. Consistent with this finding, Doukakis (2014) investigates the effect of obligatory IFRS adoption on both accruals-based and real activities-based earnings management for 22 European countries, and also finds evidence of a substitution effect. In a study of Tunisian firms, Hamza and Bannouri (2015) find that following the implementation of the 2005 Financial System Reform act, Tunisian managers engaged in real earnings management through sales manipulation. The authors therefore suggest that real earnings management is employed by Tunisian firms in a tightened regulatory environment. However, in a more recent study of Tunisian firms, Hamza and Kortas (2019) find evidence of a complementary relationship between accruals-based and real activities-based earnings management methods. The authors argue that Tunisian firms do not face greater scrutiny from regulators and thus employ both methods concurrently to achieve earnings targets. However, they also find evidence of a substitution effect when income taxation becomes the main incentive for earnings management practices. In this case, Tunisian firms substitute accrualsbased earnings management with real earnings management. Thus, their study finds evidence of both a substitutability of earnings management methods, and a complementary relationship between the two methods. In a study of Thai firms, Khunkaew and Qingxiang (2019) find evidence that firms substitute earnings management methods.

In contrast to the research findings of a substitution effect, however, Kuo et al. (2014) find that Chinese firms display a long-term positive relationship between accruals-based earnings management and real activities-based earnings management methods, which suggests that the two methods can also be employed to supplement each other in order to achieve earnings targets. Consistent with this, 
Ismail (2017) studies Egyptian firms and finds that they employ both earnings management methods concurrently. He argues that firms complement the two techniques to achieve earnings targets. However, since the majority of studies find a substitution effect, the following hypothesis is stated.

\section{H1: Firms use accruals-based and real activities-based earnings management methods as substitutes.}

Ewert and Wagenhofer (2005) argue that clearer accounting rules and stricter accounting standards result in less earnings management and a higher quality of earnings. Consistent with this argument, Ho et al. (2015) argue that IFRS adoption is likely to curb accruals-based earnings management since more principle-based accounting standards decrease the opportunistic interpretation of complex rules and force firms to comply with the intent of the standards. Further, the costs of conducting accruals-based earnings management can be expected to rise as a result of heightened outside scrutiny from the audit reform and other regulations.

Further, Lemma et al. (2013) argue that IFRS adoption increases transparency and reduces agency costs, thereby curbing earnings management. They find a negative relationship between IFRS adoption and both accruals-based and real activities-based earnings management for 44 countries. Ho et al. (2015) examine the impact of IFRS adoption upon accruals-based and real activities-based earnings management in Chinese firms and argue that higher quality accounting standards associated with IFRS and or simultaneous changes in the governance regimes introduced as part of the IFRS mandate curb accruals-based earnings management behaviour. However, real earnings management becomes easier to conduct since it is not affected by IFRS. Thus, if there is a trade-off of one earnings management method for another, firms are likely to trade off upward accruals-based earnings management for real earnings management. They find that Chinese firms are less likely to engage in accruals-based earnings management following the adoption of IFRS, and instead shift to real earnings management. Therefore, the following hypothesis is stated.

$\mathrm{H} 2$ : There is a negative relationship between accruals-based earnings management and IFRS adoption.

\section{Data and Methods}

\subsection{Data}

This research employs secondary data drawn from the Thompson Reuters Datastream financial database for 798 non-financial MENA listed firms. The countries included in the sample are Bahrain, Egypt, Jordan, Kuwait, Oman, Qatar, Saudi Arabia, Tunisia, and the United Arab Emirates. The sample selected for the study covers the period 2008-2015, inclusively. This study period spans multiple economic cycles and political events. At the time of data collection, there was no available data for this sample of countries prior to the year 2008 or past the year 2015. Financial firms are excluded from the study.

The sample selected includes firms across the following industries: energy, materials, industrials, consumer discretionary, consumer staples, healthcare, real estate, information technology, mobile telecommunications, and utilities. Firm-years that lack the necessary data to compute the dependent or independent variables are excluded from the study. Further, outliers are detected and removed. If an observation is larger than three standard deviations of the sample distribution, it is considered an outlier. After removing firm-years that lack the necessary data to compute the variables, and after removing outliers, this research examines a total number of 2,740 firm-year observations.

\subsection{Accruals-Based Earnings Management Dependent Variable}

This research employs the Modified Jones model (Dechow et al., 1995) to compute discretionary accruals to proxy for accruals-based earnings management. The Modified Jones Model is proposed by Dechow et al. (1995) as a development of the original model proposed by Jones (1991). First, total accruals are computed using the cash flow statement approach as shown in Equation 1. 


$$
T A_{t}=\text { Earnings before extraordinary items }- \text { operating cash flows }
$$

Next, firm specific parameters are obtained from Equation 2 that follows.

$$
T A_{t} /_{A_{t-1}}=\alpha_{1}\left(1 / A_{t-1}\right)+\alpha_{2}\left[\left(\Delta R E V_{t}-\Delta R E C_{t}\right) /_{A_{t-1}}\right]+\alpha_{3}\left(P P E_{t} / A_{t-1}\right)+\varepsilon_{t}
$$

where:

$T A_{t}=$ total accruals in year $\mathrm{t} . \varepsilon_{t}$ is the residual, which represents the firm-specific discretionary portion of total accruals.

$A_{t-1}=$ total assets at the end of year $\mathrm{t}-1$;

$\alpha, \alpha 2$, and $\alpha 3$ are the firm-specific parameters;

$\triangle R E V_{t}=$ revenues in year $\mathrm{t}$ less revenues in year $\mathrm{t}-1$;

$\triangle R E C_{t}=$ net receivables in year $\mathrm{t}$ less net receivables in year $\mathrm{t}-1$;

$P P E_{t}=$ gross property plant and equipment at the end of year $\mathrm{t}$.

Equation 3 is then computed to derive the nondiscretionary portion of total accruals as follows.

$$
N D A_{t}=\alpha_{1}\left(1 / A_{t-1}\right)+\alpha_{2}\left[\left(\Delta R E V_{t}-\Delta R E C_{t}\right) /_{A_{t-1}}\right]+\alpha_{3}\left(P P E_{t} / A_{t-1}\right)
$$

where:

$N D A_{t}=$ the nondiscretionary portion of total accruals.

The models are estimated at the cross-section for each industry member for at least eight observations. Discretionary accruals are then computed as the difference between total accruals scaled by lagged total assets and nondiscretionary accruals scaled by lagged total assets as follows.

$$
D A_{t}=T A_{t}-N D A_{t}
$$

\subsection{Real Activities-Based Earnings Management Proxy}

To proxy for real earnings management, abnormal production costs, abnormal discretionary expenditures, and abnormal cash flows are employed. Real earnings management can be conducted by means of reducing the cost of goods sold through the overproduction of inventory and by means of reducing discretionary expenditures, including research and development (R\&D), advertising, and selling, general, and administrative expenditures (Roychowdhury, 2006; Zang, 2012). The abnormal level of production costs is used to measure the reduction in the cost of goods sold thorough the overproduction of inventory since the fixed cost per unit declines with an increasing volume of production (Kuo et al., 2014), while the abnormal level of discretionary expenditures is used to measure the reduction in discretionary expenditures. The following model estimates the normal level production costs. The estimated residual from this equation is the abnormal level of production costs.

$$
\text { PROD }_{t} / A_{t-1}=\alpha_{1}\left(1 / A_{t-1}\right)+\alpha_{2}\left(S_{t} / A_{t-1}\right)+\alpha_{3}\left(\Delta_{t} / A_{t-1}\right)+\alpha_{4}\left(\Delta S_{t-1} /_{A_{t-1}}\right)+\varepsilon_{t}
$$

where:

$P R O D_{t}=$ the sum of cost of goods sold in year $\mathrm{t}$ and the change in inventory from $\mathrm{t}-1$ to $\mathrm{t}$;

$A_{t-1}=$ the total assets in year $\mathrm{t}-1$;

$S_{t}=$ net sales in year $\mathrm{t}$;

And $\Delta S_{t-1}=$ the change in net sales from year $\mathrm{t}-2$ to $\mathrm{t}-1$.

Equation 5 is estimated at the cross-section for each industry member for at least eight observations. The greater the amount of inventory overproduction, the higher the residual, and thus the greater is the increase in reported earnings through the reduction in the cost of goods sold. The normal level of discretionary expenditures is estimated as follows.

$$
\operatorname{DISX}_{t} /_{A_{t-1}}=\alpha_{1}\left(1 / A_{t-1}\right)+\alpha_{2}\left(S_{t-1} /_{A_{t-1}}\right)+\varepsilon_{t}
$$


where:

$D I S X_{t}=$ discretionary expenditures (the sum of selling, general, and administrative expenditures) in year $\mathrm{t}$;

$S_{t-1}=$ the net sales of the previous year.

The abnormal level of discretionary expenditures is measured as the estimated residual from the regression. Equation 6 is estimated at the cross-section for each industry member for at least eight observations. In addition to this, a third real activities-based earnings management model is employed consistent with Cohen and Zarowin (2010) and Roychowdhury (2006), which models cash flow from operations and expresses it as a linear function of sales and the change in sales in the current year. The model is estimated as follows.

$$
C F O_{t} /_{A_{t-1}}=\alpha 1\left(1 / A_{t-1}\right)+\alpha 2\left(S t / A_{t-1}\right)+\alpha 3\left(\Delta S t / A_{t-1}\right)+\varepsilon_{t}
$$

where:

CFO $=$ the cash flows from operating activities in year $\mathrm{t}$.

The normal level of cash flows from operations is computed using the estimated coefficients from Equation 7 and this variable is then subtracted from the actual cash flows from operations to derive the abnormal cash flows from operations. Equation 7 is estimated at the cross-section for each industry member for at least eight observations. Rather than employing the three proxies separately, an aggregate proxy for real activities-based earnings management is computed to capture the total impact of real earnings management, consistent with Kuo et al. (2014), as follows.

$$
\begin{gathered}
R M=- \text { Abnormal cash flows from operations }+ \text { abnormal production costs }- \\
\text { abnormal discretionary expenditures }
\end{gathered}
$$

Consistent with Kuo et al., abnormal cash flows from operations are multiplied by -1 and then abnormal production costs are added to it. By doing so, higher levels of RM indicate higher levels of real earnings management activities, as suggested by Zang (2012). Abnormal discretionary expenditures are added to abnormal cash flows from operations after multiplying abnormal cash flows from operations by -1 so that the larger the value of this aggregate proxy, the higher the utilization of sales manipulation as well as reductions in discretionary expenditures for managing earnings as suggested by Kuo et al. (2014).

\subsection{Model Specification}

This research tests whether accruals-based and real activities-based earnings management methods are used by MENA firms as substitutes or complements, and also investigates the impact of IFRS adoption on accruals-based earnings management by employing the following panel regression model.

$$
D A_{i t}=\beta_{0}+\beta_{1} R M_{i t}+\beta_{2} S I Z E_{i t}+\beta_{3} L E V_{i t}+\beta_{4} G R O W T H_{i t}+\beta_{5} D P R_{i t}+\beta_{6} I F R S_{i t}+\beta_{7} G D P_{i t}+\varepsilon_{i t}
$$

where:

$D A$ = discretionary accruals computed from the Modified Jones Model; $R M$ corresponds to the aggregate real earnings management proxy variable; SIZE = firm size measured as the natural logarithm of total assets; $L E V=$ leverage measured as total debt divided by total assets; GROWTH = growth opportunities measured as the market price per share divided by the book value per share; $D P R=$ the dividend payout ratio measured as the dividend per share divided by earnings per share; IFRS = IFRS adoption which is a dummy variable that takes the value of 1 if the firm reports its financial statements under IFRS and 0 otherwise; and GDP = the GDP growth rate;

In this model, the real earnings management proxy is regressed against discretionary accruals to identify whether firms employ both methods concurrently or substitute one for the other. A positive relationship between discretionary accruals and the real earnings management proxy would indicate 
that firms employ both methods as complements. In contrast, a negative association would indicate that firms substitute accruals-based earnings management with real earnings management. Firm size, leverage, growth opportunities, the dividend payout ratio, and the GDP growth rate are included as control variables since they may impact upon accruals-based earnings management.

Firm size is included as a control variable in this study since large firms incur relatively high reputation costs if the credibility of financial information disclosed is compromised compared to smaller firms, and enjoy the benefits of receiving better audit services which likely diminishes their earnings management capability (Lemma et al., 2013). Further, Kuo et al. (2014) argue that larger firms face greater scrutiny by auditors and regulators compared with small, rapidly growing firms whose business activities cannot be so easily observed. Leverage is controlled for in this study since high leveraged firms may tend toward earnings management in order to prevent breaches of debt covenants (Lemma et al., 2013). In contrast, higher leverage may reduce opportunistic earnings management behaviour since firms that employ debt are often subject to lender-imposed spending restrictions (Jelinek, 2007). Since growing firms might refrain from engaging in earnings management behaviour since these firms are likely to be under close scrutiny by outsiders which would make it harder to manipulate earnings opportunistically (Lemma et al., 2013), growth opportunities is included as a control variable. The dividend payout ratio is included as a control variable since earnings management is often conducted to maintain a desired payout ratio or to meet certain dividend thresholds since the payout ratio is considered to be a signal of the future growth prospects of a firm (Miller and Rock, 1985). Filip and Raffournier (2014) argue that a firm's propensity to manipulate earnings is impacted by dramatic changes in the economic environment of the firm. Therefore, the GDP growth rate is included as a control variable in this study.

\section{Results and Discussion}

\subsection{Descriptive Statistics}

Table 2 presents the descriptive statistics for the variables included in the empirical models. The mean, median, standard deviation, minimum, and maximum values are shown for the dependent and independent variables.

Table 2. Descriptive Statistics

\begin{tabular}{cccccc}
\hline Variables & Mean & Median & $\begin{array}{c}\text { Standard } \\
\text { Deviation }\end{array}$ & Minimum & Maximum \\
\hline DA & 0.004 & -0.000 & 0.140 & -0.747 & 0.796 \\
RM & -0.211 & -0.172 & 0.334 & -1.862 & 1.404 \\
SIZE & 12.628 & 12.507 & 2.407 & 6.439 & 19.505 \\
LEV & 0.197 & 0.157 & 0.180 & 0.000 & 0.806 \\
GROWTH & 1.936 & 1.466 & 1.826 & 0.110 & 25.025 \\
DPR & 37.278 & 39.60 & 34.356 & 0.000 & 100 \\
GDP & 3.719 & 3.510 & 3.059 & -5.242 & 13.375 \\
\hline
\end{tabular}

Note. This table presents the descriptive statistics for the variables included in the models. The mean, median, standard deviation, minimum, and maximum values are shown for the dependent and independent variables. DA refers to discretionary accruals computed from the Modified Jones Model; RM refers to the aggregate real earnings management proxy computed by aggregating abnormal production costs, abnormal discretionary expenditures, and abnormal cash flows; SIZE refers to firm size measured using the natural logarithm of total assets; LEV refers to leverage measured as total debt scaled by total assets; GROWTH refers to growth opportunities measured using the price-book ratio; DPR refers to the dividend payout ratio measured as dividends per share divided by earnings per share; and GDP refers to the GDP growth rate.

As shown in Table 2, the standard deviation of $R M$ is higher than that of $D A$ which indicates higher volatility for real earnings management compared with accruals-based earnings management 
for MENA firms. The mean value for $R M$ is higher than $D A$ which suggests that MENA firms engage in a greater degree of real earnings management compared with accruals-based earnings management on average. MENA firms rely on $19.7 \%$ debt financing on average with a maximum debt ratio of around $80 \%$. Further, MENA firms are characterized by a $37.28 \%$ dividend payout ratio on average.

\subsection{Correlation Analysis}

Table 3 presents the Pearson Correlation Matrix for the variables included in the empirical models to analyse the correlations between the dependent and independent variables.

Table 3. Pearson Correlation Matrix

\begin{tabular}{cccccccc}
\hline & DA & RM & SIZE & LEV & GROWTH & DPR & GDP \\
\hline DA & 1 & & & & & & \\
RM & $.253^{* *}$ & 1 & & & & & \\
SIZE & $.058^{* *}$ & $.064^{* *}$ & 1 & & & & \\
LEV & -.012 & $.142^{* *}$ & $.258^{* *}$ & 1 & & & \\
GROWTH & -.010 & $-.160^{* *}$ & $.103^{* *}$ & .001 & 1 & & \\
DPR & $.092^{* *}$ & $-.215^{* *}$ & $.113^{* *}$ & $-.235^{* *}$ & $.105^{* *}$ & 1 & \\
GDP & $047^{*}$ & $-.051^{* *}$ & $.056^{* *}$ & .021 & $.054^{* *}$ & $.042^{*}$ & 1 \\
\hline
\end{tabular}

Note. This table presents the Pearson Correlation Matrix for the variables included in the models. $D A$ refers to discretionary accruals computed from the Modified Jones Model; RM refers to the aggregate real earnings management proxy computed by aggregating abnormal production costs, abnormal discretionary expenditures, and abnormal cash flows; SIZE refers to firm size measured using the natural logarithm of total assets; $L E V$ refers to leverage measured as total debt scaled by total assets; GROWTH refers to growth opportunities measured using the price-book ratio; DPR refers to the dividend payout ratio measured as dividends per share divided by earnings per share; and GDP refers to the GDP growth rate. ${ }^{* *}$ and ${ }^{*}$ refer to the significance at the $1 \%$ and $5 \%$ levels, respectively.

As shown in Table 3, DA and the RM are significantly positively correlated at the $1 \%$ level. This potentially indicates that MENA firms complement the two earnings management methods rather than substituting one method for the other. However, in the absence of regression results, this is only indicative.

Firm size and the dividend payout ratio are significantly positively correlated with discretionary accruals at the $1 \%$ level. GDP growth is shown to be significantly positively correlated with discretionary accruals at the $5 \%$ level. This indicates that larger firms, firms which are characterized by higher dividend payout ratios, and growth in GDP are correlated with a greater degree of accrualsbased earnings management behaviour. Firm size and leverage are found to be significantly positively correlated with the real earnings management proxy variable at the $1 \%$ level, while growth opportunities, the dividend payout ratio, and GDP growth are found to be significantly negatively correlated with $R M$ at the $1 \%$ level, suggesting that larger firms and higher leveraged firms may engage in a greater degree of real earnings management, while greater GDP growth rates, firms characterized by higher growth opportunities, and higher dividend payout ratios may exhibit a lower tendency to engage in real earnings management.

\subsection{Regression Results}

The Hausman Test is computed to identify whether a panel fixed-effects or random-effects regression should be employed. The results show that a fixed-effects regression should be employed in the empirical model of this paper. Table 4 presents the Panel Fixed-Effects regression results of the empirical model which tests whether earnings management methods are employed by firms as substitutes or complements and investigates the effect of IFRS adoption on accruals-based earnings management. The maximum and mean variance inflation factor (VIF) values are also included and indicate that there is no significant problem of multicollinearity across the model variables. 
Table 4. Panel Fixed-Effects Regression Results

\begin{tabular}{ccc}
\hline Variables & Coefficient & $\begin{array}{c}\text { Expected } \\
\text { Sign }\end{array}$ \\
\hline Constant & -0.171 & \\
RM & $(-0.64)$ & - \\
SIZE & 0.236 & \\
& $(10.97)^{* * *}$ & \\
LEV & 0.018 & \\
& $(0.87)$ & \\
GROWTH & 0.038 & $(0.71)$ \\
& -0.002 & - \\
DPR & $(-0.59)$ & \\
& 0.000 & \\
IFRS & $(1.74)^{*}$ & -0.043 \\
& $(-0.98)$ \\
GDP & 0.002 & \\
& $(3.09)^{* * *}$ \\
R Squared & 0.2109 \\
Observations & 0.000 \\
Maximum VIF & 2,740 \\
Mean VIF & 1.52 \\
\hline Significance & 1.22 \\
\hline
\end{tabular}

Note. This table presents the panel fixed-effects regression results for the empirical model. The tstatistics are shown between brackets and ${ }^{* *},{ }^{* *}$, and ${ }^{*}$ refer to the significance at the $1 \%, 5 \%$, and $10 \%$ levels, respectively. Robust standard errors clustered at the firm level are used. $R M$ refers to the aggregate real earnings management proxy computed by aggregating abnormal production costs, abnormal discretionary expenditures, and abnormal cash flows; SIZE refers to firm size measured as the natural logarithm of total assets; $L E V$ refers to leverage measured as total debt scaled by total assets; GROWTH refers to growth opportunities measured as the price-book ratio; DPR refers to the dividend payout ratio measured as dividend per share divided by earnings per share; IFRS refers to a dummy variable for the IFRS adoption status; and GDP refers to the GDP growth rate.

To test Hypothesis H1 which states that firms use accruals-based and real activities-based earnings management methods as substitutes, the association between discretionary accruals and the real earnings management proxy variable is examined. Table 4 shows that the real earnings management proxy variable is significantly positively associated with discretionary accruals at the $1 \%$ level. The significant positive coefficient provides evidence that MENA firms employ both accrualsbased earnings management and real earnings management methods as complements, which is likely conducted to achieve earnings targets. Thus, MENA firms do not trade off one earnings management method for the other based on their relative costs, and this evidence further shows that accruals-based earnings management may not be difficult to employ in MENA firms and thus it is not necessary for firms to switch to real earnings management since it is more difficult to detect. It is possible that MENA firms are not heavily scrutinized by analysts and regulators, and thus are capable of employing both methods concurrently. This result is of particular importance to regulators and policy makers who should be aware that accruals-based earnings management in MENA firms is not constrained and it is therefore possible for firms to engage in both accruals-based and real activities-based earnings management methods simultaneously.

This finding provides support for the research findings of Hamza and Kortas (2019) for Tunisian firms, Ismail (2017) for Egyptian firms, and Kuo et al. (2014) for Chinese firms. However, a positive coefficient contrasts with the research findings of Zang (2012), Anagnostopoulou and Tsekrekos (2017), 
and Cohen et al. (2008) who investigate US firms, as well as Zhu et al. (2015) and Doukakis (2014) in an examination of Chinese firms and 22 European countries, respectively. Further, this finding does not provide support for hypothesis H1. IFRS adoption is found to be an insignificant determinant of discretionary accruals and thus Hypothesis $\mathrm{H} 2$ is not supported.

Regarding the control variables, only GDP growth is found to be a significant determinant of discretionary accruals. The coefficient is significant and positive at the $1 \%$ level which provides evidence that economic growth leads to a greater degree of accruals-based earnings management behaviour in MENA firms. This may be due to firms engaging in earnings management to avoid lagging behind the economy's growth rate.

\section{Conclusions}

\subsection{Conclusion}

This study addresses two research questions: (i) are earnings management methods used as substitutes or complements by firms? and (ii) what is the impact of IFRS adoption on accruals-based earnings management? The research findings provide evidence that MENA firms employ both accruals-based earnings management and real earnings management methods concurrently, which is likely conducted to achieve earnings targets. Therefore, MENA firms do not substitute the two methods and instead employ both methods as complements. Accruals-based earnings management is evidently not constrained within MENA firms. It is possible that MENA firms are not scrutinized heavily by regulators and analysts and therefore firms are capable of complementing earnings management methods as suggested by Hamza and Kortas (2019) who argue that Tunisian firms do not face significant scrutiny from regulators and thus employ both methods concurrently to achieve earnings targets. Thus, firms do not need to substitute one method for the other due to the relative costs and instead employ both simultaneously.

Further, GDP growth is found to be a significant determinant of accruals-based earnings management. Economic growth is associated with a greater degree of accruals-based earnings management in MENA firms. This may be due to firms managing earnings to avoid lagging behind the economy's growth rate.

The results presented in this study have important implications for regulators, policy makers, and auditors. Auditors, regulators, and policy makers should be aware that greater economic growth leads to a greater degree of accruals-based earnings management behaviour. Thus, during periods of economic growth, it is important to be more alert in terms of detecting earnings management behaviour. Further, firms employ both accruals-based and real activities-based earnings management methods concurrently. Thus, auditors and regulators should not focus on mitigating the use of a particular method and should pay particular attention to both methods.

\subsection{Recommendations for Future Research}

Future research could examine the classification shifting-based earnings management method and investigate whether it is employed by firms as a substitute or complement to the accruals-based and real activities-based earnings management methods. Additional country-level variables could be tested as well. Particularly, future research could investigate the potential impact of financial development on earnings management.

\subsection{Limitations}

One limitation of this study is that corporate governance variables are not included in the empirical model since there was no available data for such variables. However, such variables could have an impact upon earnings management behaviour and consequently whether firms substitute or complement earnings management methods. In addition, although the MENA region includes roughly nineteen countries, the study sample is restricted to only nine countries due to the availability 
of data at the time of writing. Further, due to missing data values necessary to compute the dependent variable for some of the MENA countries, the study sample is restricted to nine countries

Funding: This research received no external funding.

Conflicts of Interest: The authors declare no conflict of interest.

\section{References}

Anagnostopoulou, S. \& Tsekrekos, A. (2017). The effect of financial leverage on real and accrual-based earnings management. Accounting and Business Research, 47(2), 191-236.

Cohen, D., Dey, A. \& Lys, T. (2008). Real and accrual-based earnings management in the pre- and post-SarbanesOxley periods. The Accounting Review, 83(3), 757-787.

Cohen, D. \& Zarowin, P. (2010). Accrual-based and real earnings management activities around seasoned equity offerings. Journal of Accounting and Economics, 50(1), 2-19.

Dechow, P., Sloan, R. \& Sweeney, A. (1995). Detecting earnings management. The Accounting Review, 70(2), 193225.

Doukakis, L. (2014). The effect of mandatory IFRS adoption on real and accrual-based earnings management activities. Journal of Accounting and Public Policy, 33(6), 551-572.

Ewert, R. \& Wagenhofer, A. (2005). Economic effects of tightening accounting standards to restrict earnings management. The Accounting Review, 43(4), 1101-1124.

Filip, A. \& Raffournier, B. (2014). Financial crisis and earnings management: The European evidence. The International Journal of Accounting, 49(4), 455-478.

Hamza, S. \& Bannouri, S. (2015). The detection of real earnings management in MENA countries: The case of Tunisia. Afro-Asian Journal of Finance and Accounting, 5(2), 135-159.

Hamza, S. \& Kortas, N. (2019). The interaction between accounting and real earnings management using simultaneous equation model with panel data. Review of Quantitative Finance and Accounting, 53(4), 1195-1227.

Healy, P. \& Wahlen, J. (1999). A review of the earnings management literature and its implications for standard setting. Accounting Horizons, 13(4), 365-383.

Ho, L., Liao, Q. \& Taylor, M. (2015). Real and accrual-based earnings management in the pre- and post-IFRS periods: Evidence from China. Journal of International Financial Management and Accounting, 26(3), 294-335.

Ismail, M. (2017). Real earnings management versus accrual-based and its effect on firm performance: Evidence from Egypt. Alexandria Journal of Accounting Research, 1(2), 1-38.

Jelinek, K. (2007). The effect of leverage increases on earnings management. Journal of Business and Economic Studies, 13(2), 24-46.

Jones, J. (1991). Earnings management during import relief investigations. Journal of Accounting Research, 29(2), 193-228.

Khunkaew, R. \& Qingxiang, Y. (2019). Substitution between accruals-based and real activities earnings management of listed Thai firms. The Journal of Corporate Accounting \& Finance, 30(4), 99-110.

Kuo, J., Ning, L. \& Song, X. (2014). The real and accrual-based earnings management behaviors: Evidence from the split share structure reform in China. The International Journal of Accounting, 49(1), 101-136.

Lemma, T., Negash, M. \& Mlilo, M. (2013). Determinants of earnings management: Evidence from around the world. SSRN: https://papers.ssrn.com/sol3/papers.cfm?abstract_id $=2370926$.

Miller, M. \& Rock, K. (1985). Dividend policy under asymmetric information. Journal of Finance, 40(4), 1031-1051.

Roychowdhury, S. (2006). Earnings management through real activities manipulation. Journal of Accounting and Economics, 42(3), 335-370.

Schipper, K. (1989). Commentary on earnings management. Accounting Horizons, 3(4), 91-102.

Watts, R. \& Zimmerman, J. (1978). Towards a positive theory of the determination of accounting standards. The Accounting Review, 53(1), 112-134.

Zang, A. (2012). Evidence of the trade-off between real activities manipulation and accrual-based earnings management. The Accounting Review, 87(2), 675-703.

Zhu, T., Lu, M., Shan, Y. \& Zhang, Y. (2015). Accrual-based and real activity earnings management at the back door: Evidence from Chinese reverse mergers. Pacific-Basin Finance Journal, 35(1), 317-339. 
(C) 2020 by the authors. This article is an open-access article distributed under the terms and conditions of the Creative Commons Attribution (CC BY) license (http://creativecommons.org/licenses/by/4.0/). 